European journal of American studies

\title{
Americanizations of Holocaust Memory and Museum Aesthetic Experience
}

Karolina Krasuska

\section{(2) OpenEdition}

\section{Journals}

Electronic version

URL: https://journals.openedition.org/ejas/13531

DOI: $10.4000 /$ ejas. 13531

ISSN: 1991-9336

Publisher

European Association for American Studies

Electronic reference

Karolina Krasuska, "Americanizations of Holocaust Memory and Museum Aesthetic Experience" European journal of American studies [Online], 13-3 | 2018, Online since 23 January 2019, connection on 08 July 2021. URL: http://journals.openedition.org/ejas/13531 ; DOI: https://doi.org/10.4000/ejas. 13531

This text was automatically generated on 8 July 2021 .

Creative Commons License 


\title{
Americanizations of Holocaust Memory and Museum Aesthetic Experience
}

\author{
Karolina Krasuska
}

1 The key debates around the core exhibition at the POLIN Museum of the History of Polish Jews in Warsaw understandably mostly revolve around its representation of Polish-Jewish relations. ${ }^{1}$ The core "multimedia narrative exhibition" (KirshenblattGimblett, "Inside the Museum" 216), which opened in 2014, displays a thousand years of the history of Polish Jews and unfolds generally chronologically in eight sections, with the section titled "Holocaust" being the seventh ("Core Exhibition"). Accordingly, the POLIN Museum of the History of Polish Jews has not been envisioned as a Holocaust museum. Even to the contrary, following the principle that POLIN is a "museum of life" (Kirshenblatt-Gimblett, "Theater of History" 22) and the Holocaust is not the culmination of the history of Polish Jews (Engelking and Leociak, "Holocaust"), a major part of the Holocaust gallery focuses on Jewish life in Nazi-occupied Poland. ${ }^{2}$

2 How and, even why, then, talk about Americanization and specifically the Americanization of Holocaust memory in the context of this museum? The exhibition itself, showing the history of Polish Jews in an international or transnational context, contains a few American moments: a section on immigration at the turn of the twentieth century or the prominent panels on the charity American Jewish Joint Distribution Committee helping Jewish war victims in the WWI are prominent examples here. There is also the story of the beginnings of the POLIN Museum of the History of Polish Jews begins in the US. As told by creators of the museum, the opening of the United States Holocaust Memorial Museum in Washington DC (USHMM) was the inspiration of an idea to develop a museum narrating centuries of Jews in the Polish lands (Kirshenblatt-Gimblett, "Theater of History" 22). ${ }^{3}$ These beginnings are embodied in a specific person, Grażyna Pawlak, the Director of Development of the Association of the Jewish Historical Institute of Poland in the early 1990s, the contacts with the 
creator of the USHMM, Jeshajahu Weinberg, and finally, eminent American scholar, Barbara Kirshenblatt-Gimblett becoming the chief curator of the core exhibition.

3 I am not going to rehearse the by now well-publicized story of curatorial, organizational, and institutional American connections, but rather point to the significance of this initial American moment. Namely, it positioned the museum makers in a complex relation to the USHMM, which occasioned the coinage of the phrase "Americanization of the Holocaust." These convergences point to a global circulation of American and Americanized Holocaust memory, this time not through popular culture, but museums. In what follows I examine an aspect of this relation in aesthetic and ideological terms, taking as an example an emblematic segment of the USHMM exhibition, The Tower of Faces and the POLIN's installation on Jedwabne, that is, on the 1941-2 pogroms in Nazi-occupied Poland. To accomplish this I first disentangle the various meanings of "Americanization" that are used in American Studies in Europe and in Holocaust and memory studies respectively. Here, I focus especially on how Americanization has been read also in aesthetic terms (Fluck) and apply this perspective to what became known as the Americanization of the Holocaust. These theoretical peregrinations lead me to consider exhibition as film, together with museum studies critics and cultural theorist Mieke Bal. In the analytical part of the article, then, I approach The Tower of Faces and the POLIN museum's Jedwabne installation to tease out how cinematic readings of these segments add to their interpretation. At first glance, similar family photographs are used in different aesthetic frames that are key to the larger concept of the exhibitions. The POLIN's Jedwabne installation stands, then, in visible relation to The Tower of Faces. Yet it is produced not only to comply with the smallest common aesthetic denominator (Fluck, "Amerikanisierung und Modernisierung" 63), but at the same time aesthetically reconfigured to also ideologically speak to local Polish debates on the participation of Poles in the murder of Jews in Nazi-occupied Poland.

\section{Americanizations}

"Americanization" is closely related to American popular culture and its ubiquitous presence, if not domination, globally (Fluck, "Amerikanisierung und Modernisierung" 56). As such, it is used within American studies to analyze cultural phenomena worldwide, as well as within, for instance, Holocaust studies and memory studies to talk about popular culture forms shaping Holocaust memory. And this is the end of the relative consensus because the term carries nothing short of opposing meanings. These, especially in the context of American Studies, vacillate between the idealized potential of emancipatory powers inherent in popular cultural forms and the danger of cultural imperialism carried by American cultural products (Fluck, "Amerikanisierung und Modernisierung" 56). Within Holocaust studies approaches to popular culture, the negative connotations have been more significant when preeminent critics, for instance, talked about "trivialization" in the reviews of a Holocaust miniseries from 1978 (Wiesel). Reapproaching this terminological dissent from within both disciplines, historically based in different research methods and modes of reflection may be epistemologically advantageous to think about memory in transit and certain aesthetic solution in the Holocaust gallery of the POLIN museum. 
5 Talking about Americanization of culture, Winfried Fluck points to the lack of satisfactory explanatory approaches and attempts to analyze it from within an in the context of broader social and cultural processes. For Fluck, "Americanization" is a mode of culture that is determined by its projected relation to the audience, the mentality it mirrors, and its financing ("The Americanization of German Culture?"). ${ }^{4}$ Formally speaking, Americanized culture relies on reduction (24). We can view it negatively from the point of view of the disinterested aesthetic sphere where complexity is most valued. But, as Fluck stresses, reduction not only degrades existing formal characteristics, stripping them of complexity, but rather, productively, generates "new possibilities of expression and aesthetic experience" (25). In turn, these new possibilities and forms serve the purpose of greater audience accessibility (24), or we can paraphrase-the democratization of culture. As such, this greater accessibility of culture is the product of "America of the mind" (28), that is its cultural imaginary connected to "dehierarchization" and individual self-empowerment (27).

6 In other words, Americanization is not about reduction as such, but it is a means to find the smallest common aesthetic denominator ("Amerikanisierung und Modernisierung" 63) for the members of the audience. In the examples that Fluck considers this means, for instance, the development in American culture from the popular novel to silent film. While the novel still required the knowledge of language, which had exclusionary potential towards some (immigrant) audience members, the silent film was a more inclusive visual form (59-61). Americanization refers here, then, to specific cultural processes in the US from the turn of the twentieth century that only after WWII started to play a central role globally.

7 In this way Fluck attempts to add positive value to what otherwise has been looked down on in aesthetic terms. Importantly, his argument is more than political, valorizing popular culture because of its counterhegemonic potential. It is rather expressed in aesthetic terms as creating new sensibilities and new potentials for aesthetic experience that go hand in hand with idealistically democratizing political principles.

8 The concept of Americanization in the context of Holocaust memory is similarly ambivalent. Americanization implies here, however, mostly a theoretical move in a different direction. For Fluck, revalorizing Americanization has implications on how we can approach the import or influence of American cultural modes on European ones. In other words, it is the current Americanization of European culture, however understood. Only this leads him to ask about what Americanization has meant for America itself. With "Americanization of the Holocaust" the representation of a European event undergoes a set of displacements or Holocaust memory is refunctionalized within a cultural context that is originally geographically foreign to the event itself. It does not mean, of course, within the global mediascape that these specifically American representations do not return to us and influence local European collective memories of the Holocaust, another meaning of the Americanization of Holocaust memory. The "global icons", as Aleida Assman calls them (109), play precisely such a multivalent role of traveling placeholder that bear shifting ideological investments.

9 The Americanization of the Holocaust, however, has not been read in aesthetic terms, similar to Fluck's. From a critical perspective, Joost Krijnen juxtaposes two views that read Americanization of the Holocaust in what he claims are moral terms (24). The 
dyad he creates is between, on the one hand, an advocate of what we can call productive refunctionalization of the Holocaust in the US, Michael Berenbaum, who was also the project director of the USMMH, and, on the other hand, the ardent critic of the term and, at the same time of the museum itself, Alvin Rosenfeld. Berenbaum writing in early 1990s sees a virtue in retelling the story of the Holocaust so that it resonates with every American and American credo of "pluralism, tolerance, democracy, and human rights" (42). Rosenfeld, in contrast, complains about widening "the language of "Holocaust" because "it is regularly invoked by people who want to draw public attention to human-rights abuses, social inequalities suffered by racial and ethnic minorities and women, environmental disasters, AIDS, and a whole host of other things." In addition to criticizing "Holocaust" as a mode of appropriation to parochial ends, Rosenfeld, also in a normative gesture, advocates against skewing its message towards sentimentalization and optimistic perseverance against all odds. Similarly to earlier work by Hilene Flanzbaum, Krijnen wants to shift the terms of the debate beyond the moral and rather read the representations of the Holocaust in cultural terms in order to examine their function. In Flanzbuam's words "whether he likes it or not-the Holocaust has become an artifact of American culture. [Rosenfeld] certainly cannon control how or when or in what format the Holocaust will appear, but he can respond" ("The Americanization of the Holocaust" 97).

In his prominent 1999 study, Peter Novick also enters into the debate on the Americanization of the Holocaust from a cultural vantage point-descriptive and not prescriptive. Foreshadowing the memory studies boom and employing Maurice Halbwachs's framework of collective memory, he asks about the function of Holocaust memory and forgetting in the subsequent decades after the WWII. However, he is deeply skeptical about the uses of the Holocaust in American life. For him, it serves "national self-congratulation" (14) and accentuating the difference between the US and the European old world. Also, importantly, the focus on the Holocaust allows for displacing historical events in which Americans bear responsibility (cf. 15). ${ }^{5}$ How the Holocaust is represented-we can add, also aesthetically-serves then as a litmus test of the collective and its memory.

Today, within Holocaust and memory studies, the "Americanization" of Holocaust memory, even in non-normative but descriptive terms, does not seem theoretically nuanced enough, still suggesting a certain norm of what we consider "American." It is rather complicated by mnemonic models stressing transnational flows, multidirectionality (Rothberg; Craps and Rothberg; Levy and Sznaider)-tendencies that have also been shaping American Studies in this century (Graff, Basiuk, and Krasuska). But in a dialogue with Winfried Fluck and his idea of the Americanization of culture, understood in specifically historical and aesthetic terms, we can ask what "new possibilities of expression," what new points of accessibility American representations of the Holocaust generated and whether and how they have traveled. Specifically, I would like to ask these questions looking at a particular installation at the USHMM and the Holocaust gallery at the POLIN.

\section{Cinematic effects}

12 The USHMM stands not only for what has become ambivalently known as the Americanization of the Holocaust, but also as a certain specific type of the museum that 
centers around "immersion and experience" (Witcomb 359, cf. Appelbaum, Freed). This in fact mirrors the self-reflective statement on the USHMM as a narrative history museum by Jeshajahu Weinberg that it "employs design elements that involve visitors in the narrative" (231). It is also indicative of a broader museum phenomenon: as Tiina Roppola suggests citing 1999 Neil Kotler, such an experienced-centered model of the museum displaced "collection-centered" and "education-centered" model (33). Characteristically, in relation to Fluck's thinking on the Americanization of culture and the medium of film, experience-centered exhibitions or immersive exhibitions are also understood in comparison to a "good movie" (Stogner 19). As such, both museum research and Fluck's thesis of Americanization seem to unwittingly converge in Mieke Bal's theorization of exhibition as film, a useful framework to read The Tower of Faces installation at the USHMM and Jedwabne pogrom installation at the POLIN.

How to think about exhibition as film and what are the stakes? When Winfried Fluck singles out sound film as the aesthetically democratizing medium ("Amerikanisierung und Modernisierung" 65,) so immersive exhibitions seem to mirror this development in the museum world. ${ }^{6}$ As Mieke Bal writes proposing to approach exhibition as film, we use all three metaphors of (theatrical) mise-en-scène, narrative and poetry to talk about exhibition (22). These three models are combined in the model of cinema, which-as Bal stresses, similarly to Fluck-is the "art of the masses" (Bal 22) in the twentieth century or, within American Studies register, a key medium in popular culture. Practically speaking, exhibition can be effectively read "as a meaning-producing sequentiality emerging from the viewer's walk through an exhibition" (15), in which the walk mirrors the sequentiality of the film. For Bal, the model of cinema becomes especially relevant in the context of photographs-so prominent in many exhibitions-because through the movement of the viewer the photographs "take on a cinematic effect" (16). This allows us to challenge the ostensible transparency of photography as a medium and grasp "the limits of visibility inherent in time" (22). What is at stake for Bal in theorizing exhibition as film is its affective, and consequently, political potential, which constitutes a framework that seems to productively enter into a dialogue with existing readings of one of the emblematic elements in the USHMM, The Tower of Faces.

One of key design elements used in the USHMM, and bridging the three levels of the exhibition, is the multi-story installation of mostly pre-war photographs. It has been thoroughly analyzed (e.g. Hirsch, Hansen-Glucklich), and as an aesthetic and mnemonic visual solution has been mirrored or approached in multiple museums, including Yad Vashem, the Museum of Jewish Heritage in NYC, and, to a degree, in the Holocaust gallery in the POLIN. Just to remind us, The Tower of Faces is a product of scrupulous archival work of a child survivor from Eisiskes in the Polish-Lithuanian borderlands, Yaffa Eliach, herself a granddaughter of a local photographer couple. The rectangle shaped Tower is lined inside with a mosaic of just over 1000 photographs, illustrating everyday life of the Jewish population from the shtetl between 1890 and 1941 (Weinberg and Elieli 151-152). It may be termed "The end of the shtetl" in the exhibition catalog (Weinberg and Elieli 151-152), pointing to the massacre of over 4000 Jews by Nazi Shooting squads in September 1941, but it rather shows a "personalized" (Berenbaum 72) tapestry of life scenarios, as indicated also by the wall text: "The Jewish community had a rich religious culture and an energetic secular life.... In the studio, at parties and ceremonies, in homes, their [the photographers'] work portrays the life of 
the community." The sheer amount and diversity of photographs, as Michael Berkowitz has demonstrated, is not exceptional here, but rather a norm in shtetls. But as displayed here, these everyday photographs are in blatant contrast to the popular image of starkly orientalized life in pre-Holocaust Eastern Europe, inaccurately popularized, for instance, by published editions of Roman Vishniac photographs (Benton).

In Marianne Hirsch's influential reading, the Tower manages to effectively elicit identificatory reactions from the visitors through the photographs that resemble a family album, their own family album (252): "the conventional and familial nature of the images themselves manages to transcend these distances, figured spatially by the bridge that separates us [visitors] from the pictures, and to foster an affiliative look that binds the photographs to one another and us to them" (254). In this way the museum manages "to include all of its visitors in the generation of postmemory" (249) or, in a complex way, make the memories of previous generations their own. For her, it is then the genre of photographs that plays a key role in affecting the visitor.

Hirsch briefly describes entering the "tower-shaped room" with "photographic images that hover all around us" (251-252), but later in the text takes it in the direction of "the power of photographs as media of mourning" (256). This moment of spatial arrangement and in relation to photography that can be extended with Mieke Bal's cinematic reading of exhibition, only to strengthen the proposed identification between the viewers and images, images themselves, and consequently, the viewers themselves "easily transcend[ing] ethnic identity and family history" (252). It is key that the Tower provides an arbitrary temporal break in the largely chronologic exhibition. The viewer surrounded by photographs, encased in this vertical space mirrors one of key cinematic exhibition experiences in Bal's classification that she creates on the example of a different exhibition. Also, in the case of the Tower of Faces, the immersion seems to suspend to a large degree, or bend, a linear perspective (cf. Bal 31) to create the experience that Bal calls "pro-spective" (30). Referring to Deleuze, Bal claims, "[it] enfolds the viewer rather than allowing him to take in a spectacle at a distance, without involvement. The point of view of 'the fold' compels the viewer to enter the fabulation of the artwork, to travel inside and out again and emerge transformed by the experience" (31). Such "enter[ing] the fabulation of the artwork," here ostensibly unending because of the soaring tower, seems to be a central aesthetic device experientially enabling the inclusion into postmemory. Moreover, the cinematic in this installation-like a family album or the instant recognition of the photo genre as one's own-may serve as Winfried Fluck's smallest common aesthetic denominator, allowing for broadly extending membership in the generation of postmemory.

Whereas the Tower of Faces cuts through the exhibition breaking its governing temporality, the installation in the POLIN using family pictures occupies a space that uses a different visual logic. ${ }^{7}$ Eisiskes family pictures installation memorializes and personalizes a shtetl's life, a collage of Jedwabne Jewish private photographs are used to commemorate the pogrom and massacre of estimated 300 Jews in Jedwabne in 1941 that in Polish memory came to denote around two dozen pogroms after the beginning of Operation Barbarossa or the Nazi invasion of the Soviet Union in the region neighboring on Jedwabne ${ }^{8}$, as well as generally the debates around the memory of the participation of ethnic Poles in the murder of Jews in Nazi-occupied Poland (cf. Forecki). The familial photographs, with their identificatory force theorized by Hirsch, 
are used here then to activate the identificatory lines within this emblematic moment in the memory of Polish-Jewish relations.

The Operation Barbarossa section-which the Jedwabne installation is a part of-breaks the chronology of the previous parts in the Holocaust gallery devoted largely chronologically to growing repressions, life in the Warsaw Ghetto, deportations, uprising in the Warsaw Ghetto, Polish-Jewish relations and the experience of hiding. This section returns us almost two years earlier to the big picture events of political history. It consists of five installations in a squeezed pentagon-shaped room each taking up the entire wall, indicating the breaking points within the timeline of WWII and the Holocaust: Operation Barbarossa, Jedwabne and Lwów pogroms, Ponary massacre, and Wannsee conference; the space in front of the fifth wall and the wall itself is taken up by an installation mostly translating the machinery of the death camps into an array of graphs and diagrams and functions as a narrative transition to the last room of the Holocaust gallery, a sordid, rusty, acoustically irritating space on the death camp universe itself.

Upon entering the first narrow part of the squeezed pentagon, we encounter a general map of the Operation Barbarossa, the invasion and the movements of Einsatzgruppen or the shooting squads. The installation on the pogroms directly faces these, with the lifeless grey tree trunks closing the perspective of this jagged space. A grey thick horizontal block overhang dominates the pogrom installation, forcing the visitors, as if with its weight, to bend down to look at the pre-war family pictures displayed on the recessed top lighted vertical wall. This obviously physically uncomfortable architectural solution resonates with the design of the preceding room on the experience of hiding during the Holocaust. Because of this design, first we do not see the details of the photographs, but rather look at the text on the directly adjoining wall mounted table. It includes two text blocks: the curator's synopsis of the events, making clear that "Poles played a key role in the Jedwabne pogrom" and an excerpt from the influential testimony by a survivor from Jedwabne, Shmul Wassersztejn.

Only when bending or squatting, we face the collage of 48 photographs in the horizontal crevice between the overhang and the display table: a structured arrangement of pre-war black and white or sepia pictures of Jedwabne Jewish inhabitants, captioned (name, sometimes profession) and dated, displayed on a black background and probably in their original size. When compared to The Tower of Faces in Hirsch's reading, the captions may seem to situate the image, which works against their universality and thus stalls visitor's identification. Yet, it is also clear because of the captions that the logic of the collage clearly follows genealogical connections and the members of the same family are clustered together. Hirsch's "family frames", then, function differently here and may run along these exposed genealogical lines.

These relatively small, structured picture clusters, sometimes literally visually resembling pages from family albums, captioned for the following generations, are in contrast to many uses of photographs in the museum, as indicated, for instance, by Jason Francisco, that, as he claims, contribute to the effect of, among others, "part scholarly pop-up book, part multimedia kindergarten, and part solemn carnival." The stark hyperbolic multiplication of images, their intense mirroring, blowing them up to function as wallpaper that he criticizes are absent from this installation, which suggests that these "high-tech expo" techniques (Francisco) may be rather used to defamiliarize perpetrator-produced images. 
22 Also, with its architecture, the context of the family photographs display is different from the one in the USHMM. Here it is clearly not a break from the chronology, but rather its part. It is not immersive, like the Tower of Faces with Eisiskes standing for each and any shtetl, but rather pivotal for the narrative because of the wider resonance of Jedwabne. Also, contrary to the installation at the USHMM, familial frames are not spatially isolated from atrocity photography. They are displayed in direct contrast to perpetrator created images, both within the installation itself (the deeply recessed screen in the wall mounted table shows the Nazi footage of the sexual violence during the Lviv pogrom on a loop) and the neighboring wall of the Ponary massacre. ${ }^{9}$ In a cinematic reading, the thick block overhang dramatically changes the frame, forces a close-up on the photographs, the visitor's movements, the visitors "enact[ing] cinema" (33), as Mieke Bal states in a context of a different exhibition. It is not the allencompassing, Bal's "enfolding" feeling from the Tower of Faces, but rather an intense focus on them through a particular framing.

\section{Concluding Remarks}

The aesthetic museum experience of the POLIN's Jedwabne installation aesthetically resonates with The Tower of Faces at the United States Holocaust Memorial Museum. To understand this resonance it is not enough to think about Americanization or Americanizations of Holocaust memory in functional terms, however productive for the analysis of certain American cultural artifacts they may be. Thinking about the Americanization of culture in aesthetic terms, as Winfried Fluck has suggested, changes the perspective and, as I was trying to demonstrate, allows us to also see and explain additional aesthetic correspondences in Holocaust memorializations, even if in the diverging contexts of an exhibition and national memorial culture these correspondences do not really correspond. Such a reading of the Tower of Faces of the USHMM may additionally reveal what "new possibilities of expression," what new points of accessibility American representations of the Holocaust generated, also in relation to museum aesthetic experience, and, with the example of the POLIN's Jedwabne installation, how they have traveled into other settings.

Appelbaum, Ralph. “Designing an 'Architecture of Information': The United States Holocaust Memorial Museum." Curator: The Museum Journal, vol. 38, no. 2, 1995, pp. 87-94. Print.

Assmann, Aleida. "The Holocaust-a Global Memory? Extensions and Limits of a New Memory Community." Memory in a Global Age: Discourses, Practices and Trajectories, edited by Aleida Assmann and Sebastian Conrad, Palgrave Macmillan, 2010, pp. 97-117. Print. Bal, Mieke. "Exhibition as Film." (Re)Visualizing National History: Museums and National Identities in Europe in the New Millennium, edited by Robin Ostow, University of Toronto Press, 2008, pp. 15-47. Print.

Baskind, Samantha. The Warsaw Ghetto in American Art and Culture. Penn State UP, 2018. Benton, Maya. Roman Vishniac Rediscovered. Prestel, 2015. Print.

Berenbaum, Michael. After Tragedy and Triumph: Modern Jewish Thought and the American Experience. Cambridge UP, 1990. Print.

---. The World Must Know: The History of the Holocaust as Told in the United States Holocaust

Memorial Museum. Little, Brown, 1993. Print. 
Berkowitz, Michael. "Photography as a Jewish Business: From High Theory, to Studio, to Snapshot." East European Jewish Affairs, vol. 39, no. 3, pp. 389-400, 2009, doi: 10.1080/13501670903298286.

"Core Exhibition." POLIN Museum of the History of Polish Jews.

http://www.polin.pl/en/exhibitions/core-exhibition. Accessed June 22, 2018. Craps, Stef, and Michael Rothberg. "Introduction: Transcultural Negotiations of Holocaust Memory." Criticism: A Quarterly for Literature and the Arts, vol. 53, no. 4, 2011, pp. 517-21. Print.

Engelking, Barbara, and Jacek Leociak. "Holocaust 1939-1944." Polin. 1000 Year History of Polish Jews, edited by Barbara Kirshenblatt-Gimblett and Antony Polonsky, Museum of the History of Polish Jews, 2015, pp. 288-347. Print.

---. The Warsaw Ghetto: A Guide to the Perished City. Translated by Emma Harris, Yale UP, 2009. Print.

Flanzbaum, Hilene. "The Americanization of the Holocaust." Journal of Genocide Research, vol. 1, no. 1,1999, pp. 91-104. Print.

Fluck, Winfried. “Amerikanisierung und Modernisierung.” Transit, vol. 17, 1999, pp. 55-71. Print.

---. "The Americanization of German Culture? The Strange, Paradoxical Ways of Modernity." German Pop Culture: How "American" Is It?, edited by Agnes C. Mueller, The University of Michigan Press, 2004, pp. 19-39. Print.

Forecki, Piotr. Po Jedwabnem: Anatomia pamiĘci funkcjonalnej. Instytut Badań Literackich PAN, 2018. Print.

Francisco, Jason. "Polin.” jasonfrancisco.net, 1 Dec. 2014, http://jasonfrancisco.net/polin. Accessed June 22, 2018.

Freed, James Ingo. “The United States Holocaust Memorial Museum: a Dialogue with Memory." Curator: The Museum Journal, vol. 38, no. 2, 1995, 95-110. Print.

Graff, Agnieszka, Tomasz Basiuk, and Karolina Krasuska. "Introduction: Transnational American Studies: Histories, Methodologies, Perspectives." Polish Journal for American Studies, vol. 12, Spring 2018, pp. 7-20. Print.

Gross, Jan T. Neighbors: The Destruction of the Jewish Community in Jedwabne, Poland. Princeton UP, 2001. Print.

Grudzińska-Gross, Irena, and Iwo Nawrocki, editors. Poland and Polin: New Interpretations in Polish-Jewish Studies. Peter Lang Edition, 2016. Print.

Hansen-Glucklich, Jennifer. Holocaust Memory Reframed: Museums and the Challenges of Representation. Rutgers UP, 2014.

Hirsch, Marianne. Family Frames: Photography, Narrative, and Postmemory. Harvard UP, 1997. Print.

Kijek, Kamil. "For Whom and about What? The Polin Museum, Jewish Historiography and Jews as a 'Polish Cause'." Studia Litteraria et Historica, no. 6, 2017.

https://doi.org/10.11649/slh.1363. Accessed August 27, 2018.

Kirshenblatt-Gimblett, Barbara. "Inside the Museum: Curating between hope and despair: POLIN Museum of the History of Polish Jews." East European Jewish Affairs, vol. 45, no. 2-3, 2015, pp. 215-35. Print.

---. “Theater of History." Polin. 1000 Year History of Polish Jews, edited by Barbara Kirshenblatt-Gimblett and Antony Polonsky, Museum of the History of Polish Jews, 2015, pp. 19-35. Print.

Konferencja "Od Ibrahima ibn Jakuba do Anielewicza 6" w Muzeum POLIN, cz. 8." YouTube, uploaded by Muzeum Historii Żydów Polskich POLIN, 10 July 2015. 
https://www.youtube.com/watch?v=wes49xQ5so4. Accessed August 27, 2018.

Krijnen, Joost. Holocaust Impiety in Jewish American Literature. Brill | Rodopi, 2016. Print. Leociak, Jacek. Biografie ulic. O żydowskich ulicach Warszawy: od narodzin po ZagładĘ. Dom Spotkań z HistoriĄ, 2018. Print.

Levy, Daniel, and Natan Sznaider. The Holocaust and Memory in the Global Age. Translated by Assenka Oksiloff, Temple UP, 2006. Print.

Novick, Peter. The Holocaust in American Life. Houghton Mifflin, 1999. Print.

Roppola, Tiina. Designing for the Museum Visitor Experience. Routledge, 2012. Print.

Rosenfeld, Alvin H. "The Americanization of the Holocaust." Commentary, June 1995.

https://www.commentarymagazine.com/articles/witness/. Accessed August 27, 2018.

Rothberg, Michael. Multidirectional Memory: Remembering the Holocaust in the Age of

Decolonization. Stanford UP, 2009. Print.

Stogner, Maggie Burnette. "The Immersive Cultural Museum Experience-Creating

Context and Story with New Media Technology." The International Journal of the Inclusive Museum, vol. 3, no. 3, 2011, pp. 117-30. Print.

Wall text for "Jedwabne." Core Exhibition, POLIN Museum of the History of Polish Jews, Warsaw, Poland.

Wall text for "The Tower of Faces." Permanent Exhibition, United States Holocaust Memorial Museum, Washington, DC.

Weinberg, Jeshajahu. “A Narrative History Museum.” Curator: The Museum Journal, vol. 37, no. 4, December 1994, pp. 231-9. Print.

Weinberg, Jeshajahu, and Rina Elieli. The Holocaust Museum in Washington. Rizzoli International Publications, 1995. Print.

Wiesel, Elie. "Trivializing the Holocaust: Semi-Fact and Semi-Fiction." New York Times, 16 Apr. 1978, Section II, pp. 1.

https://www.nytimes.com/1978/04/16/archives/tv-view-trivializing-the-holocaustsemifact-and-semifiction-tv-view.html. Accessed August 27, 2018.

Witcomb, Amy. "Interactivity: Thinking Beyond." A Companion to Museum Studies, edited by Sharon Macdonald, Blackwell, 2006, pp. 353-361. Print.

\section{NOTES}

1. For a nuanced reflection on the debates, see Kijek. Major critical voices on the exhibition are well represented in: Grudzińska-Gross and Nawrocki. The recording of the conference celebrating the opening of the exhibition also provides multiple clues: "Konferencja „Od Ibrahima ibn Jakuba do Anielewicza 6."

2. This focus on the every-day experiences and the life in the ghettos mirrors the lead scholars' Barbara Engelking's and Jacek Leociak's major research interests (Engelking and Leociak, The Warsaw Ghetto; Leociak) and resonates with recent research developments in Holocaust memory (e.g. Baskind).

3. A similar version of the official moment was narrated by Joanna Fikus, the coordinator of the Core exhibition in a private conversation in May 2018. 
4. For the purposes of my argument, I am skipping Fluck's important point on private modes of financing American culture that he deems crucial for the development if its specific modes.

5. Novick also directs us toward more comparative approaches to memory formation in which different traumatic events are not in competition but rather circumscribe their reciprocal memory; cf. Craps and Rothberg as well as global circulation of American memory of the Holocaust-Levy and Sznaider.

6. This thought experiment, superimposing these cultural analyses with different foci, is not supposed to make them fully compatible, but rather usable to illuminate certain aspects of aesthetic transfer of mnemonic forms.

7. I am not comparing here the two permanent exhibitions as such-they function quite differently because of when and where they had been created, and because their focus is quite different. I am asking rather about a similar aesthetic segment, so characteristic for USHMM, and the functions it fulfills within these quite different exhibitions.

8. The research on 1941-1942 pogroms was catalyzed by the publication of Jan T. Gross's, Neighbors: The Destruction of the Jewish Community in Jedwabne, Poland (2001, Polish original publication 2000). It is outside the scope of this article to sketch the extent of work by such scholars as Anna Bikont, Barbara Engelking, Jan Grabowski, Joanna Tokarska-Bakir, and others.

9. I am not considering here all textual elements of the installation on pogroms, including the latest, December 2017 addition of an object to the installation-a few sets of keys that have been dug up within the Institute of National Remembrance investigation at the location of the Jedwabne massacre.

\section{ABSTRACTS}

The article interprets an emblematic segment of the United States Holocaust Memorial Museum exhibition, The Tower of Faces and the installation on the 1941-2 pogroms in Nazi-occupied Poland in the POLIN Museum of the History of Polish Jews to compare the aesthetic experience of these examples of Holocaust memorialization. It argues that using the concept of "Americanization," as it is employed in American Studies in Europe and in Holocaust and memory studies, respectively, is instrumental in analyzing the museum experience and as such may contribute to the debates on POLIN and its representation of memory.

INDEX

Keywords: Americanization, museum, Holocaust, Jewish, memory, representation 


\section{AUTHOR}

\section{KAROLINA KRASUSKA}

Karolina Krasuska is Assistant Professor at the American Studies Center, University of Warsaw, and the founding director of the research unit Gender/Sexuality at the ASC. She is the author of a monograph examining modernist poetry from a transnational, gender-oriented perspective Płeć $i$ naród: translokacje [Gender and Nation: Translocations] (2012) and a co-author of the pioneering Encyklopedia gender (2014). She is also the Polish translator of Judith Butler's Gender Trouble(Uwikłani w płeć, Warszawa 2008). Her newest book publication is a co-edited volume (with Andrea Peto and Louise Hecht) Women and the Holocaust: New Perspectives and Challenges (2015). 